HALINA PARAFIANOWICZ (Białystok)

\title{
OD AUTONOMII DO NIEPODLEGŁOŚCI: SPRAWY CZESKIE I SEOWACKIE W POLITYCE USA (1917-1918)
}

W początkowej fazie I wojny światowej sprawy czeskie i słowackie nie budziły większego zainteresowania ani zrozumienia Amerykanów, zwłaszcza z kręgów rządowych. Dopiero wraz z rozwojem wydarzeń pojawiła się szansa na ich popularyzację w USA.

W początkowym okresie działacze czescy przedstawili przede wszystkim sytuację monarchii Habsburgów, wskazując na prześladowania i ucisk narodowy w jej ramach. Informowali w ten sposób Amerykanów o despotyzmie i prawdziwym obliczu „więzienia narodów”, a zarazem o rosnących aspiracjach politycznych tychże narodów. Liczono na poparcie ich dążeń w USA, gdzie hasła wolnościowe znajdowały zwykle żywy rezonans. Szczególne oczekiwania łączono $\mathrm{z}$ prezydentem Woodrowem Wilsonem, orędownikiem narodów uciskanych i rzecznikiem zasady samostanowienia ${ }^{1} . \mathrm{Z}$ jego administracją grupy słowiańskie zaczęły łączyć szczególne nadzieje nie tylko na zrozumienie, ale pomoc i poparcie w sprawach politycznych. Spodziewano się aktywniejszego amerykańskiego zaangażowania w konflikt wojenny, z czym też łączono coraz większe nadzieje na rozwiązanie kwestii narodowych, także w monarchii Habsburgów ${ }^{2}$. Były to rachuby nader jednostronne

1 W niemałym stopniu to właśnie jego self-determination policy przyczyniła się do późniejszej legendy tego polityka w Europie Środkowej, o czym pisałam w artykule: Woodrow Wilson i jego legenda w międzywojennej Polsce, „Dzieje Najnowsze” 2001, nr 1, s. 59-70.

2 Woodrow Wilson był autorem książki The State (1889), w której sporo uwagi poświęcił problemom i ustrojowi Austro-Węgier. Z sympatią też odnosił się do Czechów, pisząc m.in.: „Żadne przeszkody, żadne rozczarowania nie mogá zmusić Czechów do zupełnego zlania się z Austrią. Duma narodowa i wspomnienie o świetnej historii, obfitującej 
i raczej życzeniowe ( wishful thinking) narodów uciskanych w Europie Środkowej i Wschodniej.

Należy pamiętać, że początkowa neutralność USA wobec światowego konfliktu w poważnym stopniu ograniczała i utrudniała aktywność organizacji etnicznych w USA, w tym także czeskich i słowackich. Dopiero wypowiedzenie wojny Niemcom 4 kwietnia 1917 r., a przede wszystkim Austro-Węgrom 4 grudnia 1917 r., stworzyło większe szanse na podjęcie kwestii narodów przez nie uciskanych, również na gruncie amerykańskim.

Jednym z gorących zwolenników i propagatorów akcji czeskiej na terenie Stanów Zjednoczonych był naturalizowany i wykształcony tam działacz Czeskiego Związku Narodowego (CZN), prawnik z Iowa, redaktor „Spravedlnost", Charles Pergler ${ }^{3}$. Był on dobrze zorientowany w amerykańskich realiach politycznych i pilnie śledził zachodzące zmiany w sytuacji międzynarodowej. Nabrał też wkrótce przekonania, że to właśnie Ameryka będzie głównym inicjatorem i twórcą powojennego ładu w świecie. Należało zatem, jak coraz częściej przekonywał współpracowników, właściwie przygotować program polityczny i pozyskać dla niego nie tylko opinię publiczną, ale i amerykańskie kręgi rządowe. Zarówno Pergler, jak i inni działacze wskazywali na konieczność współpracy, także na gruncie amerykańskim, różnych grup narodowych zamieszkujących Austro-Węgry, a zwłaszcza Słowian. Powoływanie się na wspólnotę słowiańską, uciskaną przez obcych narodowo Niemców, Austriaków czy Węgrów było istotnym argumentem, nie tylko taktycznym. Czasem też nawiązywano do panslawizmu, który wszakże w tym czasie, w związku z sytuacją Rosji oraz rozwojem ruchów narodowych, tracił znaczenie i poparcie jeszcze niedawnych jego rzeczników.

Późnym latem 1917 roku w otoczeniu prezydenta Woodrowa Wilsona i jego doradców zaczęto coraz częściej mówić o przyszłej konferencji pokojowej. Chodziło o szczegółowe wypracowanie amerykańskiego programu politycznego. Wśród najbliższych współpracowników Wilsona poczyniono pierwsze przygotowania do „walki o trwały pokój”, jak deklarowano. W tym celu, pod patronatem zaufanego doradcy prezydenta i szarej eminencji, płk.

w zdarzenia o doniosłym znaczeniu zmuszają ich do ciągłej walki z Niemcami, żyjącymi wśród nich i ze stojącym ponad nimi rządem. Czesi dążą do autonomii w tym przynajmniej zakresie, w jakim zagwarantowano ją Węgrom". W. Wilson, Ustrój państwowy Austro-Wegier, Warszawa 1916, s. 128.

3 E. Benes, My War Memoirs. Translated from Czech by Paul Selver, Boston-New York 1928, s. 118. 
Edwarda M. House'a, zaczęto kompletować sztab fachowców z różnych dziedzin. W gronie tym znaleźli się m.in. rektor City College w Nowym Jorku, dr Sidney E. Mezes (prywatnie szwagier House'a), znawca Europy Wschodniej i wykładowca Uniwersytetu Harvard, prof. Archibald C. Coolidge, dyrektor Amerykańskiego Stowarzyszenia Geograficznego, dr Isiah Bowman, historyk z Columbii, prof. James Shotwell, renomowany prawnik, David Hunter Miller oraz znany publicysta i komentator polityczny, Walter Lippmann. Niedługo potem do współpracy pozyskano wielu specjalistów z różnych dziedzin, przede wszystkim z historii, geografii, ekonomii, m.in. profesorów: Charlesa H. Haskinsa, Cliva Daya, Allyna A. Younga i wielu innych. W ten sposób sztab około 150 fachowców z różnych dziedzin, pod przewodnictwem Mezesa, tymczasowo nazwany „Inquiry Group”, rozpoczął przygotowania do przyszłej konferencji pokojowej ${ }^{4}$.

Od jesieni 1917 roku prace „Inquiry Group” przeniesiono do różnych komisji opracowu jących poszczególne zagadnienia. Skład tych zespołów, dobieranych starannie, dostosowany był do określonej tematyki. W ten sposób wyodrębniono różne grupy badawcze, do których włączono państwa bądź regiony, co stało się w przyszłości podstawą do podziału na sekcje terytorialne (Rosja i Europa Wschodnia, Ameryka Łacińska, Austro-Węgry, Europa Zachodnia itp. $)^{5}$. Niezależnie od tego powołano również sekcje specjalistyczne, m.in. etnograficzną, statystyczną, kartograficzną i inne, które pracowały równolegle. Jak potem wyliczono, w przeciągu roku intensywnych prac opracowano około 2000 raportów i rozmaitych dokumentów oraz ponad 1200 map, które miały być podstawą do prezentacji amerykańskiego stanowiska ${ }^{6}$. Wiele $z$ tych materiałów służyło i potem rozmaitym ekspertom amerykańskim na konferencji pokojowej w Paryżu.

Prof. Seymour, znawca historii Austro-Węgier, zajął się zagadnieniami tego regionu. Do współpracy przydzielono mu absolwenta Harvardu, Roberta J. Kernera, młodego historyka pochodzenia czeskiego zajmującego się

4 L. Gelfand, The Inquiry. American Preparation for Peace, 1917-1919, Yale University Press, 1963, s. 15-30, 61; J. T. Shotwell, At the Paris Peace Conference, New York 1937, s. 3-5. Autor pisze, że od września 1917 roku został włączony do tych prac, i to właśnie on miał zaproponować tymczasową nazwę "Inquiry Group”, która - ze względu na brak lepszego określenia - przy jęła się na dobre (s. 8).

5 L. Gelfand, op. cit., s. 45-46. Najliczniejsza była sekcja Rosji i Europy Wschodniej (15 osób), Ameryki Łacińskiej (12 osób), Austro-Węgier (6-7 osób).

6 L. Gelfand, op. cit., s. 30-31; S. E. Mezes, Preparations for Peace. The Inquiry, w: Edward M. House, Charles Seymour, eds., What Really Happened at Paris. The Story of the Peace Conference, 1918-1919, New York 1921, s. 7. 
tematyką słowiańską, który w przyszłości został wykładowcą w Berkeley ${ }^{7}$. Był on, podobnie jak Robert H. Lord, jednym z pierwszych specjalizujących się w historii Europy Wschodniej uczniów prof. Archibalda C. Coolidge'a. Do nich to głównie działacze czescy i słowaccy, na czele z Tomášem G. Masarykiem, kierowali memoranda i petycje w sprawach przyszłości monarchii Habsburgów. Zagadnieniom Austro-Węgier, spośród 263 raportów „Inquiry” dotyczących spraw europejskich, poświęcono 52 raporty ${ }^{8}$.

W trakcie prac "Inquiry” nie obyło się bez zgrzytów, tym bardziej że coraz częściej przedstawiciele różnych grup etnicznych, o sprzecznych nieraz interesach, próbowali wpływać na prace komisji ekspertów. Przesyłano jej reprezentantom literaturę propagandową i różne memoranda, zabiegano o rozmowy oraz „zasypywano" ich prośbami i petycjami. Prace w poszczególnych sekcjach nabrały tempa, choć i tam nie brakowało napięć i konfliktów ${ }^{9}$.

Niebawem, także wśród członków "Inquiry", pojawiły się zarzuty pod adresem arbitralnego i nader aktywnego House'a, narzucającego nieraz swoje pomysły i poglądy. Pretensje również zgłaszano z Departamentu Stanu, gdyż początkowo jego pracownicy nie uczestniczyli w tych przygotowaniach, bądź co bądź ściśle związanych z polityką zagraniczną USA. Dopiero od stycznia 1918 roku, już po słynnym 14-punktowym orędziu Wilsona, włączono przedstawicieli Departamentu Stanu do udziału w pracach „Inquiry”, co powszechnie uznano za przejaw nie tylko większego zainteresowania USA sprawami europejskimi, ale i krok w określeniu amerykańskiej polityki zagranicznej wobec jej poszczególnych regionów.

Późną jesienią 1917 roku uaktywniły się organizacje czeskie i słowackie w Stanach Zjednoczonych, co częściowo związane było z pracami „Inquiry”, ale przede wszystkim z możliwością wypowiedzenia przez USA wojny Austro-Węgrom. Rozwój wydarzeń wojennych i coraz większa amerykańska aktywność w światowej polityce budziły nadzieje, zwłaszcza grup słowiańskich w USA, na zaangażowanie się tego mocarstwa w rozwiązywanie nabrzmiałych problemów w Europie Środkowej. Organizowano zebrania, dyskusje,

7 Robert J. Kerner był autorem bodaj pierwszej amerykańskiej bibliografii dotyczacej Europy słowiańskiej, Slavic Europe: Selected Bibliography in the Western European Languages, Comprising History, Languages and Literatures, Cambridge: Harvard University Press, 1918.

8 L. Gelfand, op. cit., s. 131, 185. Rosji i krajom bałtyckim poświęcono 82 raporty, Bałkanom 63, Niemcom 47 i aliantom 19.

9 L. Gelfand, op. cit., s. 45-58. 
mityngi, a na jednym z nich 28 listopada 1917 r. wystosowano specjalne pismo do Kongresu, w którym wyjaśniano stosunek amerykańskich Czechów i Słowaków do wydarzeń wojennych. Jego tekst opublikowano także w Biurze Prasowym Słowian (BPS) ${ }^{10}$. Jest to bardzo charakterystyczny dokument, który zrodził się w obliczu spodziewanej wojny z Austro-Węgrami. Przede wszystkim podkreślano w nim proaliancką, a zarazem antyhabsburską postawę ludności słowiańskiej, zwłaszcza tej w USA, oraz deklarowano pełną lojalność wobec nowej ojczyzny - Ameryki. W ten sposób wskazywano na zbieżność celów walki ze wspólnym wrogiem, jak również próbowano zabezpieczyć interesy rodaków w Stanach Zjednoczonych (podobnie czyniły inne grupy etniczne, m.in. bardziej aktywni Polacy). Chodziło przede wszystkim o uniknięcie deportacji tych wszystkich czeskich i słowackich imigrantów z monarchii habsburskiej, którzy jeszcze nie posiadali obywatelstwa amerykańskiego.

Poczynania Czechów i Słowaków (a podobnie czynili Polacy, Serbowie czy Chorwaci) nie padały wszak na podatny grunt i miały wciąż niewielki rezonans. Podstawową barierą pozostawał fakt, że USA nie były jeszcze w stanie wojny z Austro-Wegrami. Departament Stanu ani Kongres nie wykazywały większego zainteresowania w ogóle Europą Środkową, a politycy amerykańscy nadal nie widzieli potrzeby oficjalnej wypowiedzi na temat - jak to określano - „wewnętrznych spraw” monarchii habsburskiej. Również amerykańska opinia publiczna miała bardzo mgliste wyobrażenie nie tylko o sprawach czeskich i słowackich, ale i o sytuacji w Europie Środkowej w ogóle. W prasie centralnej ${ }^{11}$ ukazywały się jedynie sporadycznie wzmianki i komentarze na temat Austro-Węgier czy regionu, a prasa etniczna, często lokalna, nie miała możliwości dotarcia ze swymi informacjami do szerszych kręgów opinii publicznej. Gwoli ścisłości warto dodać, że sprawy międzynarodowe nie były, ani nie są dzisiaj, z wyjątkiem ważnych dla nich kwestii, w centrum zainteresowania Amerykanów.

Wydarzenia w Rosji, jej klęska militarna i załamanie się wschodniego frontu były wszak pilnie i z niepokojem śledzone w kręgach rządowych USA. Miały też zapewne bezpośredni związek z ewolucją amerykańskiego stanowiska wobec monarchii habsburskiej i wypowiedzeniem jej w końcu wojny. Ostatecznie więc 4 grudnia 1917 r. Stany Zjednoczone wypowiedziały wojnę

10 BPS, pod przewodnictwem Perglera, powstało wiosną 1917 roku w Nowym Jorku, a niedługo potem jego siedzibę przeniesiono do Waszyngtonu. Biuro odegrało ważną rolę w popularyzacji problematyki słowiańskiej w USA.

11 Nawet wpływowy i prestiżowy „New York Times” jeszcze niewiele się tą tematyką zajmował (o czym świadczy też sam indeks). 
Austro-Węgrom. W orędziu do Kongresu prezydent Wilson wskazał na moralny aspekt tej decyzji, gdyż USA - co podkreślał - występowały przeciwko ciemiężcy milionów ludzi różnych narodowości i wasalowi militarystycznych i ekspansywnych Niemiec. Przystąpienie Ameryki do wojny miało, jak zapewniał prezydent, położyć temu kres i umożliwić narodom podjęcie decyzji o własnym losie ${ }^{12}$.

Przystąpienie USA do wojny z Austro-Węgrami było nowym i ważnym czynnikiem w rozwoju sytuacji międzynarodowej. Wprawdzie prezydent zastrzegał, że Stany Zjednoczone nie są bezpośrednio zainteresowane przebudową Austro-Węgier, niemniej sam fakt wypowiedzenia wojny przez USA wydawał się być czynnikiem sprzy jającym aspiracjom politycznym narodów monarchii Habsburgów. W każdym bądź razie tak to zostało zinterpretowane przez aktywistów niepodległościowych czeskich i słowackich, którzy $\mathrm{z}$ radością i nadzieją powitali wypowiedzenie wojny przez USA Austro-Węgrom $^{13}$.

Już na początku grudnia 1917 roku podjęto kolejną próbę prezentacji spraw czeskich i słowackich, o których sami zainteresowani - z powodów taktycznych - zaczęli coraz częściej mówić „czechosłowackie”. CZN wystosował specjalne memorandum do prezydenta ${ }^{14}$ oraz szefa Wydziału Bliskowschodniego ${ }^{15}$ w Departamencie Stanu, znakomitego prawnika i autora wielu prac o prawie konstytucyjnym, dra Alberta Hutchinsona Putney'a. Był on bodaj pierwszym wysokim urzędnikiem w Departamencie Stanu, który podjął tematykę słowiańską. Wynikało to w dużej mierze już z samego faktu kierowania przezeń tym wydziałem, ale i autentycznego zainteresowania problematyką regionu. Życzliwy stosunek Putney'a do słowiańskich dążeń niepodległościowych, w tym także czeskich i słowackich, odegrał pewną rolę przy wypracowywaniu oficjalnego stanowiska USA wobec tych zagadnień. Nie bez znaczenia były też zabiegi działaczy czeskich, a zwłaszcza Perglera,

12 R. S. Baker, W. E. Dood, eds., The Public Papers of Woodrow Wilson, New York 1926 , v. I, s. 132-142. Wilson, choć potem interpretowano to życzeniowo, wyraźnie stwierdził: (...) „We do not wish in any way to impair or to rearrange the Austro-Hungarian Empire. It is no affair of ours what they do with their own life, either industrially or politically. We do not purpose or desire to dictate to them in any way. We only desire to see that their affairs are left in their own hands, in all matters, great or small."

13 E. Beneš, Světová válka a naše revoluce. Vzpomínky a úvahy z bojů za swobodu národa, Praha 1928, v. II, s. 133.

14 A. S. Link, ed., Woodrow Wilson Papers, University of Princeton Press, v. 45, s. $223-224$.

15 W powołanym w 1909 roku Wydziale Bliskowschodnim znajdowały się obok Abisynii i Egiptu także m.in. Austro-Węgry, Niemcy i Rosja. 
który nawiązał z nim kontakt bezpośredni i systematycznie dostarczał literaturę oraz petycje w sprawach czechosłowackich. W jednym z memorandum CZN stwierdzono kategorycznie, że dla Czechów i Słowaków nie do przyjęcia jest dalsza egzystencja Austro-Węgier w dotychczasowej formie. W kilka dni później, 12 grudnia 1917 r., Pergler w wywiadzie dla „Washington Post” nawiązał do tego memorandum i rozwinął jego sformułowania. Popierając dążenia wolnościowe wszystkich uciskanych narodów, zaakcentował potrzebę odbudowy niepodległego państwa Czechów i Słowaków ${ }^{16}$.

Wydaje się, że fakty te miały przede wszystkim związek z pracami „Inquiry". Na bazie dotychczasowych raportów i ekspertyz przygotowano dla prezydenta i Departamentu Stanu memoranda o sytuacji w Europie. Działacze czescy i słowaccy, podobnie jak przedstawiciele innych grup etnicznych w USA, próbowali w ten sposób wpłynąć na stanowisko Wilsona w podstawowych dla nich kwestiach. Uznawano bowiem, że prezentacja zagadnień, a czasem nawet ich zasygnalizowanie właściwym osobom z establishmentu, może być przydatne przy podnoszeniu tej tematyki, a w konsekwencji w ich rozwiązywaniu. Równolegle więc przesyłano memoranda i różne sprawozdania do ekspertów „Inquiry”, jak również członków gabinetu oraz innych polityków, na których poparcie liczono. Czasem też kierowano je do polityków wrogo nastawionych w nadziei, że w ten sposób zmieni to ich nastawienie.

Nie przeceniając wagi tych zabiegów warto wszak pamiętać, że odegrały one pewną rolę, choć trudną do należytego wyważenia. Podobnie też zachowywały się inne grupy etniczne, zabiegające o dotarcie do ludzi ze sfer rządowych USA. Działalność Ignacego Jana Paderewskiego i jego osobiste kontakty z amerykańskimi politykami (zwłaszcza House'em, by ograniczyć się do tego przykładu), miały także znaczący wpływ na dalszy rozwój sprawy polskiej ${ }^{17}$. Choć do dziś dla wielu dyskusyjny może być stopień i rezultat takiego oddziaływania, nie można wszak zakwestionować jego użyteczności.

W orędziu do Kongresu z 28 stycznia 1918 r., słynnym i znanym potem jako czternaście punktów Wilsona, amerykański prezydent wypowiedział się na temat przyszłości powojennego świata. Był to, jak się powszechnie spodziewano, program polityczny oparty głównie na wynikach prac "Inquiry”. Ale, jak wykazały potem wnikliwe badania, wiele jego punktów nosiło wyraźny ślad osobistych poglądów i przekonań Wilsona. Oczywiście znane mu

16 Ch. Pergler, America in the Struggle for Czechoslovak Independence, Philadelphia 1926, s. 47.

17 M. M. Drozdowski, Ignacy Jan Paderewski. Zarys biografii politycznej, Warszawa 1981, s. 93-137. 
były ekspertyzy „Inquiry” i memorandum z 22 grudnia 1917 r., które posłużyło za punkt wyjścia, ale prezydent przeredagował je i uzupełnił wedle własnego uznania. Wilson - jak wynika ze źródeł - odręcznie poczynił liczne korekty w niektórych sformułowaniach, zwłaszcza dotyczących Polski ${ }^{18}$.

W punkcie 10 stwierdzono: „Ludy Austro-Węgier, których miejsce między państwami chcemy widzieć zapewnione i zabezpieczone, powinny otrzymać najswobodniejszą możliwość autonomicznego rozwoju" 19.

Jak widzimy jest to sformułowanie ogólnikowe, a jego postulatywność i bliżej niesprecyzowana autonomia nie mogły satysfakcjonować Czechów i Słowaków, których aspiracje polityczne do tego czasu znacznie wzrosły. Hasło niepodległości, początkowo nieśmiało stawiane jedynie przez nielicznych działaczy czeskich i słowackich, znalazło do tego czasu poparcie nie tylko wielu amerykańskich Czechów i Słowaków, ale i polityków krajowych. Rozwój wydarzeń wojennych, a zwłaszcza klęski państw centralnych i rewolucja w Rosji, budziły coraz większe nadzieje na upadek starego systemu. To z kolei radykalizowało programy polityczne uciskanych narodów Austro-Węgier.

Orędzie styczniowe Wilsona, mimo niekwestionowanej jego doniosłości, spotkało się z mieszanymi uczuciami i różną reakcją. Ograniczymy się do interesującej nas tutaj kwestii. Wiedeń był zadowolony, zwłaszcza z punktu 10, który z kolei rozczarował działaczy niepodległościowych czeskich i słowackich, zarówno w kraju, jak i za granicą. Masaryk, który spodziewał się ze strony amerykańskiej dalej idących deklaracji, był bardzo zawiedziony ${ }^{20}$.

Beneš wspominał potem tak: „Punkt dziesiąty wywołał u nas i u naszych przyjaciół więcej niż rozczarowanie, boć pamiętaliśmy dobrze, że równo przed miesiącem - w chwili wypowiedzenia wojny Austro-Węgrom - zaznaczył Wilson dość wyraźnie, że pragnie Austrię osłabić, bądź nawet przekształcić. Nie ulegało wątpliwości, że Wilson nie opowiadał się za całkowitym zniszczeniem monarchii habsburskiej" ${ }^{21}$.

18 W. Johnston, Reflections on Wilson and the Problems of World Peace, w: Arthur S. Link, ed., Woodrow Wilson and the Revolutionary World, 1913-1921, Chapel Hill 1982, s. $207-208$.

19 Wybór dokumentów do nauki prawa międzynarodowego, opr. K. Kocott i K. Wolfke, Wrocław-Warszawa 1978, s. 46.

20 T. G. Masaryk, Rewolucja światowa, Instytut Wydawniczy „Renaissance”, Warszawa-Kraków-Poznań-Lwów (b.r.w.), t. II, s. 362-363; E. Ludwig, Defender of Democracy. Masaryk of Czechoslovakia, New York 1936, s. 163.

21 E. Beneš, Odrodzenie narodów. Z upoważnienia autora przełożył dr W. Bełza, Instytut Wydawniczy „Renaissance”, Warszawa-Kraków-Poznań-Lwów (b.r.w.), s. 454-455. 
Sformułowanie o autonomicznym rozwoju ludów Austro-Węgier odbiegało zasadniczo od oczekiwań tychże i przyniosło zawód oraz rozgoryczenie, zwłaszcza amerykańskim Czechom i Słowakom. W prasie czeskiej i słowackiej w USA wskazywano nieraz na enigmatyczny ton orędzia, choć otwarcie nie krytykowano tej wypowiedzi. Zdawano sobie doskonale sprawę z tego, że publiczna polemika $z$ orędziem prezydenta czy krytyka jego wypowiedzi, do której przywiązywał taką wagę, byłaby posunięciem nierozważnym, niedyplomatycznym, nieskutecznym, a może nawet szkodliwym. Uznano więc, że był to kolejny krok USA w sprawach także środkowoeuropejskiej polityki, którą - jak zakładano - należało ukierunkować i aktywizować.

Orędzie styczniowe Wilsona, mimo ogólnikowości i postulatywności niektórych jego punktów, budziło wszak zrozumiałe nadzieje na poparcie przez USA dążeń wolnościowych wielu narodów. Na gruncie amerykańskim Polacy, Czesi, Słowacy, a także Serbowie i Chorwaci starali się to wykorzystać do rozległej akcji propagandowej. Spotkania, odczyty i publiczne dyskusje przypominały amerykańskiej opinii publicznej o istnieniu kwestii narodowych, koniecznych do rozwiązania w najbliższej przyszłości. Odwoływano się, nawiązując do wypowiedzi prezydenta, do moralnego zadośćuczynienia krzywdom narodów ciemiężonych i sprawiedliwości międzynarodowej. Działacze czescy i słowaccy w USA przy każdej sposobności wskazywali (a wspierali ich w tym względzie też Polacy oraz Serbowie), że monarchia habsburska była już przeżytkiem, gdyż narody ją zamieszkujące dążyły do pełnej samodzielności. Podkreślano przy tym, iż brały one czynny udział w zmaganiach wojennych, wspierając w ten sposób wysiłki aliantów. Deklarowano też zwiększony udział wojsk czechosłowackich na Zachodzie we wspólnej walce $\mathrm{z}$ państwami centralnymi22.

Podobnie jak inne grupy etniczne w USA, także działacze czescy i słowaccy zaktywizowali w tym czasie wysiłki, by dotrzeć ze swoimi postulatami do amerykańskich osobistości politycznych, a zwłaszcza do Komisji Spraw Zagranicznych w Senacie. Nieprzypadkowo bowiem tak wiele listów i petycji, zwłaszcza ze stycznia-lutego 1918 roku, adresowano właśnie do członków tejże Komisji i jej przewodniczącego, sen. Williama Stone'a. Była to próba wprowadzenia kwestii czeskich, jako przedmiotu dyskusji, na kolejne posiedzenie Komisji, co - jak się spodziewano - miało zmienić politykę USA w tym względzie.

22 H. A. Miller, What Woodrow Wilson and America Meant to Czechoslovakia, w: Czechoslovakia. Twenty Years of Independence, ed. by Robert J. Kerner, Los Angeles 1940, s. 75-76. 
W jednym z listów z lutego 1918 roku Pergler przedstawił sen. Stone’owi 11-punktowy program czechosłowacki. Wyraźnie w nim stwierdził, że niejasne obietnice autonomii narodom słowiańskim w ramach Austro-Węgier nie odpowiadały już ich aspiracjom politycznym. Faktycznym dążeniem tych ludów, ciemiężonych od wieków przez Habsburgów, była odbudowa własnej państwowości. Czesi i Słowacy opowiedzieli się za wspólnym państwem, wolną i suwerenną republiką, do której prawo wywalczyli - jak argumentował Pergler - dotychczasową postawą. Ponadto, ich udział w armii we Francji, Włoszech i Rosji oraz polityczne przywództwo Masaryka zasługiwało, jak podkreślał, na uznanie tych dążeń niepodległościowych przez sojuszników, a zwłaszcza USA. Pergler apelował do Amerykanów o poparcie planów odbudowy republiki Czechów i Słowaków, „członków tego samego narodu, których jedyną różnicą był fakt, że Słowacy byli prześladowani przez Węgrów, a Czesi przez Niemców w Austrii” "23. W ten sposób nawiązywano do idei państw narodowych, którą popierał Wilson. Przekonywano słabo zorientowanych Amerykanów, że Czechosłowacja będzie państwem narodowym.

Te sugestywne i dobrze dobrane argumenty spotkały się z życzliwą reakcją niektórych senatorów. Pergler przy okazji deklarował chęć współpracy i pełną prezentację senackiej Komisji Spraw Zagranicznych sygnalizowanych tu ledwie kwestii. Była to świadoma, acz wciąż mało skuteczna, próba pozyskania amerykańskich kręgów politycznych dla idei odbudowy niepodległego państwa Czechosłowaków. Stąd idea Czechosłowacji (choć Słowacy woleli Czecho-Słowacji) i narodu państwowego - Czechosłowaków.

Stany Zjednoczone nadal zwlekały z oficjalną wypowiedzią w kwestii odbudowy państw narodowych w Europie Środkowej i Wschodniej, a powodem tej zwłoki był przede wszystkim stosunek do Austro-Węgier. W amerykańskich kręgach rządowych ugruntowane było przekonanie, że uniezależnienie monarchii habsburskiej spod kontroli Niemiec będzie już samo w sobie rozwiązaniem wielu problemów. Politycy amerykańscy, na czele z prezydentem, przez dłuższy czas liczyli na zawarcie separatystycznego pokoju z Austro-Węgrami. Świadczą o tym m.in. tajne rokowania teologa, profesora Grinnell College z Iowa, pacyfisty i znanego „apostoła wilsonizmu", George'a Herrona z austriackim prawnikiem, prof. Heinrichem Lammaschem i przywódcą opozycji węgierskiej, hr. Michałem Károlyem. Przeciągające się i niełatwe rokowania (luty 1917 - kwiecień 1918) miały 
za cel głównie oderwanie Wiednia od wpływów Berlina ${ }^{24}$. Ich ostateczne zerwanie, zdaniem niektórych badaczy, otworzyło dopiero realne szanse na zainteresowanie Amerykanów postulatami czeskimi. Także sekretarz stanu Robert Lansing niejednokrotnie wskazywał, że na zmianę amerykańskiej polityki $\mathrm{w}$ tej kwestii i wilsonowską self-determination policy duży wpływ miały nieudane rokowania o separatystyczny pokój z monarchią Habsburgów 25 .

Od wiosny 1918 roku, głównie dzięki sprzyjającym okolicznościom międzynarodowym oraz wysiłkom działaczy narodowych, hasła niepodległościowe Słowian, w tym czeskie i słowackie, trafiały także w USA na bardziej podatny grunt. Wydarzeniem szeroko komentowanym w kręgach politycznych aliantów był kongres narodów uciskanych przez Austro-Węgry. W rezolucji końcowej kongresu rzymskiego z 10 kwietnia 1918 r. stwierdzono, że uciskane narody monarchii habsburskiej domagają się pełnej niepodległości. Zapowiedziano ich ścisłą współpracę w dalszej bezkompromisowej walce o niezawisłość, apelując zarazem o międzynarodowe poparcie tych wysiłków. Rezolucja spotkała się z aprobatą Włoch, a premier Vittorio Orlando przyjął delegację kongresu na audiencji 11 kwietnia 1918 r. ${ }^{26}$ Niedługo potem rządy Francji i Anglii, choć w formie mniej zobowiązującej, wyraziły również swoje poparcie dla dążeń wolnościowych Słowian.

Obrady kongresu narodów uciskanych przez Austro-Węgry spotkały się także z pewnym zainteresowaniem amerykańskich kół rządowych i Departamentu Stanu. W niemałym stopniu było to zasługa dobrego informatora, jakim był amerykański poseł w Rzymie, Thomas Nelson Page. Był on zorientowany w położeniu Austro-Węgier i pilnie śledził zachodzące tam zmiany, jak również sam przebieg kongresu. Jego raporty, ze szczegółowym nieraz opisem zmian wewnętrznych w monarchii habsburskiej, wskazywały na wyraźną radykalizację programu politycznego narodów zamieszkujących $\mathrm{Au}$ stro-Węgry 27.

24 E. M. House, The Intimate Papers of Colonel House, Arranged as a Narrative by Charles Seymour, New York 1928, v. III, s. 375-377; S. Osuský, The Secret Peace Negotiations between Vienna and Washington, "The Slavonic Review” 1925-26, v. IV, s. $657-668$.

25 R. Lansing, War Memoirs of Robert Lansing, The Bobbs-Merril Co., Indianopolis-New York 1935, s. 262-266.

26 H. Batowski, Rozpad Austro-Weggier, 1914-1918 (Sprawy narodowościowe i działania dyplomatyczne), Kraków 1982, s. 211-212.

27 Papers Relating to the Foreign Relations of the United States (FRUS), 1918, Supplement 1, The World War, s. 795-797. 
Deklaracja końcowa kongresu narodów uciskanych przez Austro-Węgry, jak i raporty Page'a były z uwagą przyjęte przez Departament Stanu, co jeszcze bynajmniej nie oznaczało konkretnych zmian w amerykańskiej polityce wobec tego regionu. Ale w kołach establishmentu, juz po zerwaniu rokowań z Wiedniem, powoli dojrzewała myśl, by kwestiami monarchii habsburskiej zająć się dokładniej. Naturalnie, wymagało to pełniejszego obrazu wydarzeń, a zwłaszcza informacji o aspiracjach i ruchach narodowych wewnątrz monarchii.

Niemałą rolę w sprawach czeskich odegrał wspomniany już wcześniej Albert H. Putney. Wiosną 1918 roku, na polecenie Lansinga, przygotował on obszerne i szczegółowe memorandum o sytuacji Austro-Węgier. Bardzo rozbudowany 236-stronicowy dokument końcowy pt. Stowianie w Austro- Wegrzech przedstawił on Lansingowi 9 maja 1918 r. ${ }^{28}$ Wiele w nim uwagi poświęcił dążeniom narodowym Słowian, opowiadając się wyraźnie za ich „słusznymi żądaniami”. Osobny rozdział traktował o zabiegach i wysiłkach Czechów oraz Słowaków w celu stworzenia własnego państwa. W wielu stwierdzeniach Putney'a można się doszukać śladów inspiracji i sformułowań oraz argumentacji Perglera, z którym był w kontakcie i na bieżąco współpracował.

Nawiązując do tak silnej w amerykańskich kręgach rządowych moralistyki, Putney wyrażał pełną aprobatę dla aspiracji niepodległościowych Słowian. Przedstawił zarazem dodatkowe argumenty przemawiające za ogłoszeniem oficjalnego stanowiska USA w tej sprawie. Podkreślał, że amerykańska deklaracja, będąca wyrazem uznania i poparcia dążeń narodowych, odegra dużą rolę w dalszym rozwoju wydarzeń wojennych.

Drugą część wypowiedzi Putney'a cechował typowy pragmatyzm amerykański. Podkreślał on bowiem, że oprócz wydźwięku moralnego, co miało wzbudzić powszechną sympatię dla Ameryki w świecie, poparcie przez USA dążeń wolnościowych Słowian zachęci te narody do formowania własnych oddziałów zbrojnych w całej Europie, a tym samym do szybszego zakończenia wojny. Jak argumentował dalej Putney, wzmoże to wszędzie propagandę przeciwko państwom centralnym i wzmocni opozycję parlamentarną w samej monarchii habsburskiej. Na gruncie amerykańskim zaś, jak twierdził,

28 B. Miller Unterberger, The United States, Revolutionary Russia, and the Rise of Czechoslovakia, University of North Carolina Press, 1989, s. 127; V. Mamety, The United States and East Central Europe, 1914-1918: A Study in Wilsonian Diplomacy and Propaganda, Princeton 1957, s. 253. 
zaktywizuje 2-3 milionową grupę Słowian do bardziej zdecydowanego poparcia także wysiłku wojennego USA ${ }^{29}$.

Memorandum Putney'a niedługo potem zostało rozpropagowane wśród urzędników Departamentu Stanu, a jego treść wywołała ożywione dyskusje. Generalnie aprobowano jego wywody i dostrzegano użyteczność takiej deklaracji USA. Niemniej, głównie ze względu na stanowisko Wilsona, także Lansinga, nie spieszono się z ogłoszeniem oficjalnej enuncjacji. Była to typowa gra na zwłokę i manewr dyplomatyczny. Chodziło bowiem o niewiązanie się, jak uważano przedwczesne, jakimikolwiek zobowiązaniami i obietnicami wobec sojuszników, a tym bardziej wobec narodów oczekujących pomocy i poparcia ze strony USA.

Dopiero miesiąc potem, 29 maja 1918 r. (co też należy łączyć z wizytą Masaryka w USA), w publicznym oświadczeniu Lansing wypowiedział się na temat kongresu narodów uciskanych przez Austro-Węgry. Stwierdził on m.in., że jego przebieg był „obserwowany z dużym zainteresowaniem przez rząd USA, a narodowe aspiracje Czechosłowaków i Jugosłowian, opowiadających się za wolnością, zyskały szczerą sympatię amerykańskiego rządu" 30 .

Jak widzimy enuncjacja ta była bardzo ogólnikowa i mówiła jedynie o sympatii dla aspiracji narodowych, ale nie wyrażała poparcia dla dążeń niepodległościowych tych narodów. Taka deklaracja nie mogła być też uznana jako zapowiedź rozczłonkowania monarchii habsburskiej, do czego zmierzały ruchy niepodległościowe. Samą zaś wypowiedź Lansinga rozmaicie interpretowano, gdyż każda ze stron - w zależności od oczekiwań i potrzeb inaczej to rozumiała. W państwach centralnych deklarację amerykańską komentowano w sposób dla nich dogodny, wskazując że Austro-Węgry skłonne są wciąż do modyfikacji dotychczasowej polityki narodowościowej31.

Oświadczenie Lansinga z 29 maja 1918 r. nie spełniło oczekiwań czeskich działaczy niepodległościowych, choć postarali się je wykorzystać dla celów propagandowych. A zatem wypowiedź amerykańskiego polityka interpretowali życzeniowo, bo chcieli $\mathrm{w}$ niej widzieć zapowiedź uznania przez USA dążeń niepodległościowych Czechów i Słowaków. Politycy czescy traktowali to jako swoisty punkt zaczepienia, krok wstępny w formułowaniu amerykańskiego stanowiska wobec monarchii habsburskiej, a więc i spraw czeskich. Tym usilniej więc zabiegali o dotarcie $\mathrm{z}$ postulatami i programem politycz-

\footnotetext{
29 Ch. Pergler, op. cit., s. 82-90.

30 FRUS, 1918, Supplement 1, s. 808-809.

31 Jiří Há jek, Wilsonovská legenda v dějinách C̆SR, Praha 1953, s. 52-53.
} 
nym do znaczących osobistości rządowych Stanów Zjednoczonych. Była to przemyślana taktyka, obliczona na osiągnięcie dalekosiężnego celu.

Sekretarz stanu oraz prezydent unikali oficjalnych i wiążących wypowiedzi, choć ten pierwszy w memorandum do Wilsona z 30 maja $1918 \mathrm{r}$. wskazywał na nieuchronność rozpadu Austro-Węgier, a w konsekwencji i powstanie tam nowych państw. Dążenia niepodległościowe Polaków, Czechów i innych narodów, będących dotychczas prowincjami upadającego imperium, powinny być - zdaniem Lansinga - uznane i poparte przez USA. Proponował on prezydentowi publiczne oświadczenie w tej materii, wskazując na jego korzystne następstwa ${ }^{32}$. Ciekawe, że te wywody Lansinga nie pokrywały się z jego publicznymi enuncjacjami na ten sam temat, w których był bardzo ostrożny. Amerykański sekretarz stanu, choć przekonany o potrzebie zmiany stanowiska wobec Austro-Węgier, nie wypowiedział się w podobny sposób publicznie. Być może spowodowane to było, jak twierdził też sam zainteresowany, głównie powściągliwością i ostrożnością Wilsona, który był głównym twórca polityki zagranicznej USA, a sekretarz stanu tylko jego „pomocnikiem". Zresztą ich różnice zdań w wielu kwestiach polityki zagranicznej będą z czasem powiększać się, co doprowadzi do wzrastających zadrażnień i konfliktów, a w końcu rezygnacji Lansinga ze stanowiska sekretarza stanu.

Amerykanie, jak widać, byli nadal bardzo ostrożni z deklarowaniem swego stanowiska w sprawie niepodległości państwa Czechów i Słowaków. Wprawdzie okazano im pewne gesty i sympatię, ale USA nie wyrażały nadal oficjalnego poparcia dla ich dążeń niepodległościowych. W kołach rządowych wciąż panowało przekonanie, że uniezależnienie się Austro-Węgier spod kontroli Niemiec w konsekwencji także rozwiąże problemy wewnętrzne monarchii, w ramach której zapewni się autonomię narodom ją zamieszkującym. Przewidywano ewentualne ubytki terytorialne na rzecz Serbii czy Włoch oraz Polski, ale decyzje szczegółowe w tej sprawie odkładano na przyszłość. Stany Zjednoczone nie wypowiadały się jeszcze za dezintegracją Austro-Węgier, co w oczywisty sposób implikowało ich stosunek do akcji niepodległościowej Czechów i Słowaków, choć oni chyba nie do końca zdawali sobie z tego sprawę. Dla amerykańskich polityków przekonywujący był bowiem argument propagandy habsburskiej tam zadomowionej, że egzystencja Austro-Węgier bez ziem czeskich jest niemożliwa.

32 J. Kalvoda, The Genesis of Czechoslovakia, Boulder 1986, s. 294-295. 
Nie bez znaczenia były również obawy przed „bałkanizacją” Europy Środkowej, co przejawiało się często w raportach dyplomatycznych, memorandach Departamentu Stanu i dyskusjach gabinetowych. Informacje o wydarzeniach środkowoeuropejskich docierały do USA ze znacznym opóźnieniem, a i nie były one szczególnym punktem zainteresowania amerykańskich czynników rządowych. Wiedza w ogóle o sprawach europejskich była raczej niewielka, a zachodzące tam błyskawiczne zmiany traktowano zazwyczaj jako sytuację przejściową. Raporty dyplomatyczne o rozpadzie Rosji i Austro-Węgier oraz tworzeniu nowych państw traktowano w USA z niedowierzaniem, a komentarze i konkluzje amerykańskich dyplomatów z placówek europejskich kwitowano nieraz w Waszyngtonie jako przesadne i przedwczesne $^{33}$. Amerykanie, choć tego od nich oczekiwano, nie byli jeszcze gotowi do wypowiedzenia się na temat urządzenia powojennej Europy Środkowej.

Od wiosny 1918 roku problematyka środkowoeuropejska coraz częściej gościła nie tylko $\mathrm{w}$ amerykańskich mass mediach, ale i debatach gabinetowych. Wizyta Masaryka w Stanach Zjednoczonych (5 maj - 20 listopad 1918) przyczyniła się w dużej mierze do popularyzacji tematyki czeskiej i słowackiej. Masaryk, m.in. dzięki kontaktom prywatnym i koneksjom rodzinnym (ożeniony był z Charlottą Garrigue z Nowego Jorku), utrzymywał od wielu lat kontakty z USA, a zwłaszcza z amerykańskimi ośrodkami uniwersyteckimi. Przebywał tam z wykładami w 1902 i 1907 r., dzięki czemu poznał nie tylko kręgi uniwersyteckie, ale i ludzi biznesu oraz polityków. Jak sam przyznawał, pielęgnował starannie te kontakty, które w czasie I wojny światowej okazały się bardzo przydatne, zwłaszcza w jej końcowej fazie. USA bowiem stawały się ważnym, a nieraz decydującym, elementem w międzynarodowej polityce. Tam też kierowały się nadzieje na uzyskanie poparcia dla sprawy niepodległości Czechosłowacji, tym bardziej że modyfikacji uległy rachuby polityczne związane z Rosją, która „wypadła z gry”.

Wizyta Masaryka w USA przypadła na końcowy okres I wojny światowej, a zarazem wzmożonych i burzliwych dyskusji na temat urządzenia powojennego świata. Działacze niepodległościowi starali się zatem wykorzystać zaistniałą sytuację dla prezentacji własnych postulatów politycznych. Czesi i Słowacy zaktywizowali w tym czasie poczynania na gruncie amerykańskim, szeroko informując tutejszą opinię publiczną o własnych dążeniach niepodległościowych. Komentarze w prasie, pamflety i rozmaite anglojęzyczne broszurki dla szerszego kręgu odbiorców, a z drugiej strony oddziaływanie na

33 Bogate materiały archiwalne (m.in. Decimal File) w Nayional Archives sa tego dowodem. 
polityków przygotowało z czasem bardziej podatny grunt dla haseł niepodległościowych tych narodów. Tym bardziej, że zaistniało wiele nowych faktów, które ułatwiły zajęcie przez USA bardziej zdecydowanego stanowiska wobec rozpadających się Austro-Węgier ${ }^{34}$.

Szerokie kręgi amerykańskiej opinii publicznej coraz częściej deklarowały sympatię, życzliwość i poparcie dla ruchów wolnościowych i państw narodowych w Europie Środkowej i Wschodniej. Tego rodzaju hasła odpowiadały także wilsonowskiej moralizatorskiej frazeologii odnośnie polityki jego administracji. Ale Masaryk, wbrew późniejszej legendzie, przyjęty był raczej chłodno i z rezerwą przez amerykański establishment. Jeszcze wtedy był on praktycznie nieznany w USA ${ }^{35}$. Okazano mu wprawdzie pewne względy, o które postarali się jego rodacy w USA. Na Union Station - z inicjatywy sen. Adolpha J. Sabatha powitała go liczna delegacja amerykańskich kongresmenów i senatorów, z udziałem m.in. Gilberta M. Hitchcocka, Williama S. Kenyona, Philipa M. Burneta i in., co nagłośniono w prasie ${ }^{36}$. Ale przyszło mu sporo poczekać na oficjalne audiencje zarówno u prezydenta, jak i u Lansinga. W międzyczasie zatem podjął usilne działania propagandowe wśród rodaków w USA (co doprowadziło do mowy pittsburskiej) oraz amerykańskich mediów.

Politycy czescy doceniali potęgę i znaczenie prasy amerykańskiej, której systematycznie dostarczano informacje o sprawach czeskich i słowackich, choć nie zawsze $z$ nich korzystano. Wspomniane wcześniej BPS oraz rozmaite pisma czeskie i słowackie w USA przesyłały także materiały agencyjne i komentarze, spełniając $\mathrm{w}$ ten sposób użyteczną rolę. Z czasem więc dziennikarze i publicyści amerykańscy, często korzystając $z$ tych materiałów informowali rodzimą opinię publiczną o sytuacji w Europie Środkowej. Masaryk po latach pisał o długu wdzięczności wobec dziennikarzy, wymieniając kilku z nich, m.in. Williama Harda, Irę Bennetta, Dixona z Bostonu i Martina z Cleveland ${ }^{37}$.

34 H. Parafianowicz, W drodze do niepodległości Czechostowacji: wizyta Tomasa G. Masaryka w USA, w: Wojsko, spoteczeństwo, historia, Białystok 1995, s. 237-247.

35 W. Sukiennicki, East Central Europe During World War I: From Foreign Domination to National Independence, ed. by Maciej Siekierski, preface by Czesław Miłosz, Boulder 1984, v. I, s. 893.

36 V. Mamatey, op. cit., s. 258; O. Odložilik, The Czechs, w: Joseph P. O'Grady, ed., The Immigrants' Influence on Wilson's Peace Policies, University of Kentucky Press, 1967, s. 213.

37 T. G. Masaryk, The Making of State. Memoirs and Observations, 1914-1918. Prepared and with Introduction by Henry Wickham Steed, New York 1927, s. 221. 
Kwestiom czechosłowackim sporo życzliwej uwagi poświęcił również sekretarz Wilsona, od 1917 roku dyrektor Komitetu Informacji Publicznej - George Creel. Latem 1918 roku, dzięki artykułom i sympatycznym komentarzom oraz wywiadom z Masarykiem, które ukazywały się w prasie centralnej, a zwłaszcza w "New York Times" i „Washington Post”, hasła niepodległościowe Czechów i Słowaków docierały do szerokich kręgów społeczeństwa amerykańskiego. Przywódca czeski zaś stał się, z jeszcze niedawno mało znanego "profesora Masaryka”, znanym w USA myślicielem i politykiem ${ }^{38}$.

Także w kołach politycznych Waszyngtonu, a zwłaszcza w Departamencie Stanu, podjęto ożywione dyskusje na temat Europy Środkowej, choć starano się nie nadawać temu rozgłosu. Wilson wciąż unikał oficjalnej wypowiedzi w sprawie przyszłości Austro-Węgier, a więc i zmian terytorialnych z tym związanych. Mimo licznych zabiegów Charlesa Crane'a, Adolpha J. Sabatha oraz francuskiego ambasadora w Waszyngtonie, Julesa Jusseranda ${ }^{39}$, amerykański prezydent najwyraźniej zwlekał z przyjęciem Masaryka. Ten ostatni zaś nadal zabiegał o taką audiencję, zdając sobie doskonale sprawę z jej wagi ${ }^{40}$. Niezależnie bowiem od jej przebiegu i poruszonych zagadnień byłby to i tak znaczący gest polityczny. Doceniał jego wagę Masaryk, ale tego chyba właśnie Wilson starał się wciąż unikać (o czym też świadczą późniejsze ich rozmowy, do których doszło w czerwcu 1918 roku).

Jednak w amerykańskich kręgach rządowych następowała w tym czasie powolna ewolucja stanowiska wobec Austro-Węgier, a w konsekwencji i spraw czechosłowackich. Oficjalnie USA uczyniły pewne gesty i ogłosiły wyrazy sympatii dla aspiracji narodowych Czechów i Słowaków. W gruncie rzeczy uznano już fakty dokonane i liczono się z możliwością rozpadu monarchii habsburskiej. Pod koniec czerwca 1918 roku w Departamencie Stanu rozważano ewentualność uznania Czechosłowackiej Rady Narodowej jako zalążka przyszłego rządu ${ }^{41}$. Z pewnością rozmowy Masaryka z Wilsonem miały na to wpływ.

38 Kwestiom tym wiele miejsca poświęcili, m.in. J. Kalvoda, B. M. Unterberger, George Kovtun i in.

39 FRUS, 1918, Supplement 1, s. 813-814. Pismo J. Jusseranda do Lansinga z 15 czerwca 1918 r. Jusserand opowiadał się za oficjalnym uznaniem Czechosłowackiej Rady Narodowej i proponował uzgodnienie stanowiska Francji i USA w tej kwestii.

40 T. G. Masaryk, Rewolucja..., t. I, s. 431.

41 J. Kalvoda, op. cit., s. 378-382. 
Niektórzy politycy z amerykańskiego establishmentu nadal opowiadali się za zachowaniem, acz przebudowanych, Austro-Węgier, zakładając też ich pewne, choć bliżej niesprecyzowane, straty terytorialne. Może dlatego m.in. Amerykanie wcześniej poparli dążenia niepodległościowe Polaków oraz Jugosłowian, co oznaczało pewne ubytki terytorialne Austro-Węgier, ale nie ich całkowitą dezintegrację. Inaczej natomiast wyglądał stosunek Amerykanów (podobnie jak i początkowo aliantów) do ruchu niepodległościowego czechosłowackiego. Prezydent Wilson, sekretarz stanu Lansing, jak i urzędnicy w Departamencie Stanu długo zajmowali postawę wyczekującą i nie chcieli się wypowiadać w tej kwestii. Przed I wojną światową Austro-Węgry były trwałym i, jak wielu polityków uważało, niezbędnym elementem Europy. Nie wyobrażano sobie zatem, że mogło być inaczej, zwłaszcza w początkowej fazie wojny. Rozwijający się z czasem nurt niepodległościowy Czechów i Słowaków oraz ich żądania daleko wykraczały poza plany Ententy wobec Europy Środkowej. Wprawdzie okazywano sympatię i wykonywano pewne gesty wobec aspiracji narodowych Czechów i Słowaków, ale początkowo Francja i Anglia, ani tym bardziej USA, nie spieszyły się z poparciem dla CRN i ruchu niepodległościowego. Były one przekonane o potrzebie zachowania monarchii habsburskiej, choć okrojonej i zreformowanej. Poparcie zaś niepodległości Czechosłowacji oznaczałoby, tak czy inaczej, uznanie rozpadu państwa Habsburgów, gdyż bez historycznej Bohemii nie mogłoby ono istnieć. Stanie się to dopiero w końcowej fazie wojny, kiedy klęska militarna i kryzys polityczny Austro-Węgier przesądzi o ich losie, a USA zdecydują się na poparcie czechosłowackiego ruchu niepodległościowego. 